\title{
Symulacyjna metoda analizy bezpieczeństwa pojazdu szynowego
}

\begin{abstract}
W artykule omówiono wybrane zagadnienia zwiqzane z analiza bezpieczeństwa pojazdów szynowych $z$ wykorzystaniem modeli symulacyjnych. Przedstawiono metody obliczeń $i$ wyniki symulacji przeprowadzonych dla oszacowania trwatości zmęczeniowej węzła konstrukcyjnego.
\end{abstract}

\section{Wstęp}

Problematyka bezpieczeństwa $\mathrm{w}$ systemach eksploatacji pojazdów szynowych jest rozpatrywana głównie $\mathrm{w}$ aspekcie zaistnienia wypadku. W transporcie kolejowym termin bezpieczeństwo sprowadza się najczęściej do zagrożenia środowiska naturalnego, pojawiającego się w związku z przewozem materiałów niebezpiecznych i prawdopodobieństwem zaistnienia katastrofy. Analizy i statystyki z ostatnich lat przedstawiają, że ok. $80 \%$ katastrof $\mathrm{w}$ transporcie spowodowane jest działalnością operatora (błędne lub celowe oddziaływanie człowieka na system), $10 \%$ to zawodność urządzeń, a pozostałe $10 \%$ to wpływ czynników zewnętrznych (tj. oddziaływanie przyrody np. zwierzęta leśne wybiegające na tory, burza, mgła).

System techniczny pojazdów szynowych, analizowany w aspekcie bezpieczeństwa, stanowi element składowy przestrzeni: czlowiek - technika - środowisko. System ten może znajdować się w pięciu podstawowych stanach [3]:

- stan bezpieczeństwa oznacza funkcjonowanie systemu zgodnie z wymaganiami;

- stan poczucia zagrożenia bezpieczeństwa wynika z pobudek racjonalnych lub irracjonalnych, związanych $\mathrm{z}$ możliwością zaistnienia utraty stanu bezpieczeństwa;

- stan zagrożenia bezpieczeństwa jest to taki stan, w którym operator zapobiega sytuacji- niebezpiecznej spowodowanej błędem własnym lub innego operatora, albo uszkodzeniem obiektu technicznego;

- stan zawodności sprawności ma miejsce wtedy, kiedy system traci w pełni albo·częściowo swoją sprawność wskutek np. uszkodzenia eksploatowanych obiektów;

- stan zawodności bezpieczeństwa oznacza stan katastrofy, np. wypadki $\mathrm{z}$ udziałem ludzi lub zniszczenie istotnej części systemu.

Pojęciami związanymi z oceną systemu eksploatacji pojazdów szynowych są jakość, niezawodność i bezpieczeństwo.
W literaturze spotyka się wiele rozwiązań, przykładów i analiz dotyczących modeli symulacyjnych niezawodności [1], [2], [3], [4]. Opisywane modele można podzielić $\mathrm{w}$ zależności od sposobu i rodzaju realizowanych zadań. Sama analiza niezawodnościowa określonego pojazdu szynowego opiera się na wynikach przetwarzania danych pomiarowych, pozyskiwanych w procesach: kontroli - weryfikacji kwalifikacji elementów pojazdów i maszyn, i jest prowadzona głównie w zakładach naprawczych.

\section{Modele symulacyjne w analizie bezpieczeństwa}

Modele symulacyjne znajdują duże zastosowanie w różnych dziedzinach nauki, można też je wykorzystać w badaniach i projektowaniu bezpieczeństwa pojazdów szynowych. W technice symulacji tworzy się często złożone modele całego systemu i procesów w nim zachodzących, którymi możemy manipulować w taki sposób, aby w rezultacie dokonać oceny funkcjonowania badanego systemu, podlegającego wpływom zmiennych warunków zewnętrznych. Procedury wykorzystywane są przy symulacji eksploatacji, kontroli i korygowania parametrów jakościowych i niezawodnościowych podzespołów pojazdów szynowych, od etapu projektowania (symulacja w CAD), poprzez produkcję (symulacja w CAM i CAP) aż do kontroli jakości (CAQ) i serwisu (CAS), przy zabezpieczeniu niezawodności eksploatacyjnej.

Modele symulacyjne $\mathrm{w}$ kolejnictwie, związane $\mathrm{z}$ analizą bezpieczeństwa mają obszerne zastosowanie, gdyż umożliwiają między innymi:

- sprawne, bezkolizyjne zarządzanie logistyczne, dzięki śledzeniu zachowań wirtualnych modeli złożonych systemów i procesów;

- racjonalną analizę doboru materiału na elementy konstrukcji pojazdów szynowych;

- prognozowanie i analizowanie następstw wystąpienia usterek prowadzących do powstania zagrożenia;

- $\quad$ kontrolę czy dany pojazd szynowy jest bezpieczny dla otoczenia. 
$\mathrm{W}$ infrastrukturze systemu związanego $\mathrm{z}$ pojazdem szynowym $\mathrm{w}$ pierwszym kroku modelowania stanu bezpieczeństwa należy znaleźć odpowiedzi na pytania:

- czy istnieją (lub mogą być zbudowane) adekwatne modele umożliwiające podejmowanie optymalnych (lub bliskich optymalnym) decyzji?

- czy można zbudować adekwatne modele nie wymagające bezpośredniego wyprowadzania optymalnych rozwiązań?

Po podjęciu decyzji, następnym krokiem jest wybór odpowiednich modeli fizycznych podsystemu, po nim tworzy się modele matematyczne i na ich bazie konstruuje modele symulacyjne. Realizując te kroki należy pamiętać o założeniach wynikających z wymagań formalnych (normy, przepisy, zalecenia), ograniczeniach (np. dotyczących dostępności pakietów symulacyjnych) i przesłankach technicznoorganizacyjno-ekonomicznych.

Wprowadzenie techniki cyfrowej $\mathrm{w}$ dziedzinie sterowania ruchem kolejowym spowodowało, że konieczne stało się opracowanie nowych kryteriów oceny urządzeń, ze szczególnym uwzględnieniem bezpieczeństwa ruchu. W różnych krajach Europy przyjęto różne zalecenia i uregulowania prawne gwarantujące zapewnienie właściwego poziomu bezpieczeństwa transportu kolejowego. Bezpieczeństwo pojazdów szynowych musi być zgodne np. z norma CENELE [7], która narzuca twórcom konieczność spełniania wymagań norm jakościowych ISO 9001.

\section{Metody i narzędzia}

Przy ocenie i prognozowaniu stanów bezpieczeństwa obiektów technicznych stosuje się głównie metody matematyczne bazujące na miarach statystycznych, odniesionych do procesów stochastycznych [1], [3], [4]. W opisach struktur hierarchicznych często wykorzystuje się pojęcia i metody teorii informacji np. przy konstruowaniu kryteriów klasyfikacji stanów oraz metody informatyki np. w zakresie automatyzacji pozyskiwania danych $\mathrm{z}$ relacyjnych baz danych.

Wybrana przykładowo w tej pracy metoda „Grey - system theory" [3], [6] służy do prognozowania stanu obiektów w przypadkach, gdy analizowane są np. wielkość zużycia współpracujących elementów, ilość uszkodzeń elementów, wielkość drgań elementów tocznych. Sprawdzenie bezpieczeństwa polega na symulacji eksploatacji pojazdu przy zakładanej znajomości intensywności uszkodzeń i popełnianych błędów przez maszynistę oraz po określeniu wartości początkowych poszczególnych prawdopodobieństw i czasów badań symulacyjnych. Wyniki zastosowania tej metody wskazują na dużą zgodność wartości prognozowanych z rzeczywistymi, otrzymanymi z pomiarów. Wykorzystuje się ją w procesach kontroli stanu technicznego środków transportu - również szynowego, jako jeden z elementów systemu monitorowania [3].

Obecnie, duże, specjalne pakiety symulacji wykorzystuje się przy analizie wypadków, jak również przy predykcji procesów eksploatacji pojazdów szynowych (diagnostyka, niezawodność, bezpieczeństwo) oraz przy analizie pracy całej infrastruktury kolejowej.

W niniejszej pracy stosuje się oryginalne programy-moduły symulacyjne, zbudowane na bazie pakietu VisSim \& Analyze, służące do komputerowego wspomagania realizacji zadań związanych z szacowaniem wskaźników bezpieczeństwa wybranych modeli podsystemów pojazdów szynowych.

\section{Wybrany przykład zadania}

Ocena trwałości i współczynnika bezpieczeństwa wytrzymałości zmęczeniowej wybranego elementu konstrukcyjnego pojazdu szynowego.

Przedstawiony na rys. 1 węzeł konstrukcyjny poprzecznicy ramy wózka z przyspawanym wspornikiem zawieszenia przekładni ukazuje strefę pęknięć zmęczeniowych obserwowanych $\mathrm{w}$ eksploatacji $\mathrm{i}$ podczas badań stanowiskowych [6].

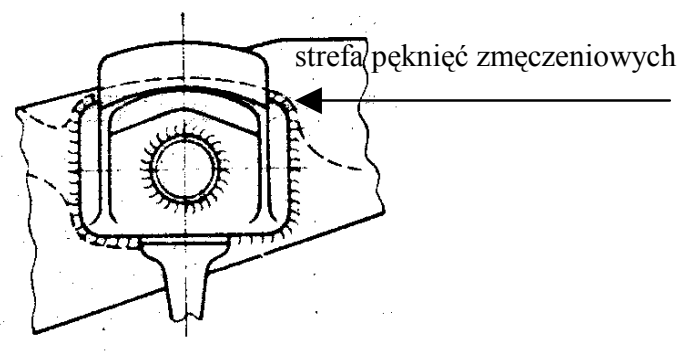

Rys. 1. Węzeł konstrukcyjny poprzecznicy ramy wózka z przyspawanym wspornikiem zawieszenia przekładni wg [6]

Wytrzymałość zmęczeniową konstrukcji rozpatrywanego węzła określa związek między trwałością a funkcją gęstości widmowej naprężeń w spoinie połączenia wspornika $\mathrm{z}$ poprzecznica, dla różnych prędkości jazdy (np. $40 \div 100 \mathrm{~km} / \mathrm{h}$ ). Wykładnik potęgowy $m$ krzywej wytrzymałościowej i granica wytrzymałości węzła $\sigma_{-1 k}$ przyjmowane są z danych tablicowych (dla danego rodzaju materiału), na poziomie ufności 0,95 . Zadaniem podstawowym jest znalezienie wartości estyma trwałości węzła, określonej wg [6] wzorem:

gdzie:

$$
T_{c}=\frac{\left[\sigma_{-1 k}\right]^{m} N_{0} \varphi^{m}}{2^{m / 2} \Gamma\left(\frac{m+2}{2}\right)} \frac{1}{\sum_{i} p_{t i}\left[2 \int_{0}^{\infty} f^{2 / m} S(f) d f\right]_{i}^{m / 2}}
$$

$$
\begin{array}{lll}
f & - & \text { częstotliwość zmian cyklu obciążenia, } \\
m & - & \text { wykładnik potęgowy krzywej zmę- } \\
& \text { czeniowej, } \\
{\left[\sigma_{-1 k}\right]} & - & \text { min wartość granicy wytrzymałości } \\
& \text { zmęczeniowej, }
\end{array}
$$




$$
\begin{array}{ll}
\Gamma\left(\frac{m+2}{2}\right)- & \text { funkcja gamma Eulera, } \\
N_{0} & -\quad \begin{array}{l}
\text { ilość badanych zmęczeniowo próbek } \\
\text { połączenia, }
\end{array} \\
\varphi & -\quad \begin{array}{l}
\text { współczynnik asymetrii cyklu obcią- } \\
\text { żenia danego elementu - połączenia, } \\
\text { gęstość widmowa naprężeń dyna- } \\
\text { micznych w elemencie, } \\
\text { prawdopodobieństwo czasu jazdy z } \\
\text { prędkością } v_{i} .
\end{array} \\
P t i &
\end{array}
$$

Algorytm obliczenia trwałości węzła konstrukcyjnego w oparciu o wzór (1), przy zastosowaniu symulacji komputerowej, przedstawić można następująco:

- ustalenie prędkości jazdy $v_{0}$ (zgodnie $\mathrm{z}$ planem jazdy na danym odcinku trasy),

- wybór generatora losowego (np. o rozkładzie Gaussa albo rozkładzie równomiernym) i losowe (addytywne) zaburzenie przebiegu prędkości jazdy,

- wyznaczenie prawdopodobieństwa Pti czasu jazdy z prędkością $v_{i}$ (z histogramów· rozkładów prędkości jazdy na danej trasie),

- wyznaczenie wariancji procesu z gęstością widmową $S(f)$ naprężeń dynamicznych

$$
2 \int_{0}^{\infty} f^{\frac{m}{2}} S(f) d f
$$

- na podstawie danych: widm naprężeń dynamicznych $S(f)$ we wsporniku, przy· różnych prędkościach jazdy oraz znajomości Pti następuje obliczenie trwałości $T c$.

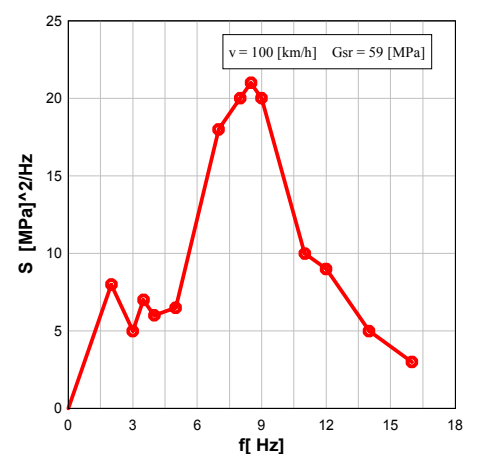

Rys. 2. Przykładowe widmo naprężeń dynamicznych $S(f)$ we wsporniku zawieszenia przekładni

Do analizy numerycznej niniejszego przykładu został wykorzystany histogram rozkładu prędkości jazdy na zadanej trasie wybrany $z$ literatury [6]. Korzystając z pakietu symulacyjnego VisSim przeprowadzono symulację zmian losowych nałożonych na zdeterminowane planem prędkości jazdy. Można zaobserwować, iż na niższym rysunku $3 b$ ) jest przedstawiona zadawana ustalona przedziałami prędkość jazdy. W rzeczywistości nie jest ona taka idealna, co można zaobserwować na rysunku 3a) przez wykorzystanie generatora losowego o rozkładzie Gaussa i generatora o rozkładzie równoległym.

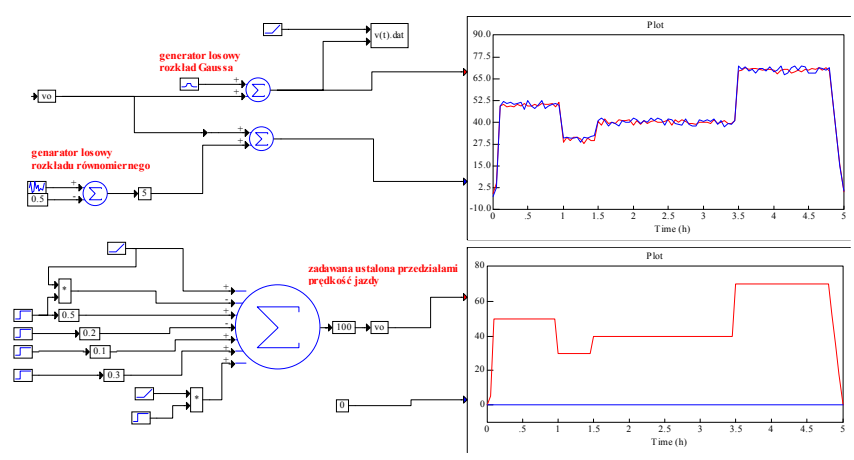

Rys. 3. Symulacja losowych zmian prędkości jazdy a) z wykorzystaniem generatorów, b) zadana prędkość jazdy

$\mathrm{Na}$ rys. 4 przedstawiono wykres symulowanych zmian prędkości jazdy, na podstawie, którego określano wartości prawdopodobieństwa $P_{t i}$ czasu jazdy z prędkością $v_{l}$ na danej trasie. W obliczeniach wykorzystano pakiet MathCad.

Po wyznaczeniu $P_{t i}$ i wstawieniu pozostałych danych (zakładanych) wartości do wzoru (1) można obliczyć trwałość zmęczeniową węzła.

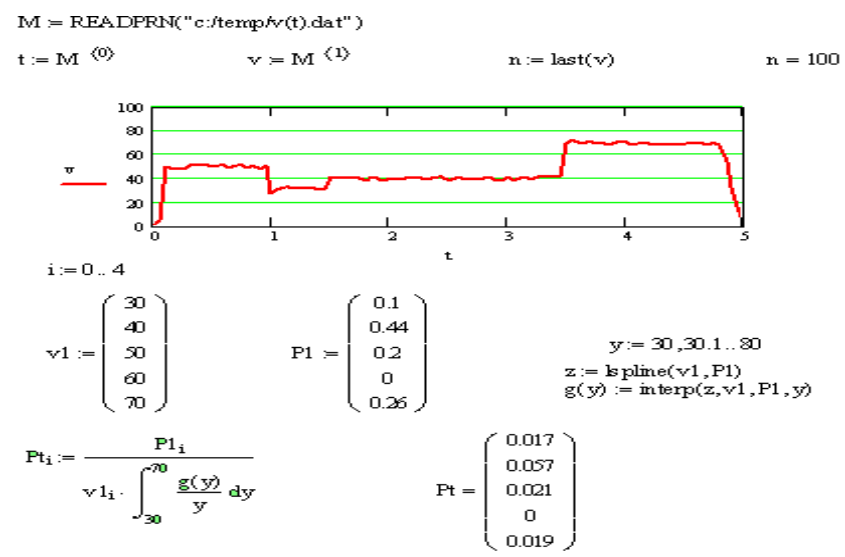

Rys. 4. Określenie wartości prawdopodobieństwa Pti czasu jazdy z prędkością vi (na danej trasie)

Po wyznaczeniu $\mathrm{P}_{\mathrm{ti}}$ i wstawieniu pozostałych już danych wartości do wzoru (1) możemy obliczyć trwałość.

\section{Uwagi końcowe}

Analizując uzyskane wyniki badań symulacyjnych, można stwierdzić, że:

- Wartość wielkości trwałości zmęczeniowej uzyskiwana z obliczeń symulacyjnych, pozwala efektywnie określić poziom bezpieczeństwa ramy wózka zależny od prędkości jazdy i dokonać optymalnego doboru rodzaju materiału konstrukcji węzła. 
- Pakiety symulacyjne VisSim i Mathcad sa przydatne do rozwiązania postawionych problemów bezpieczeństwa złożonych systemów w kolejnictwie. Zauważono'komplementarność ich cech w rozwiązywaniu zadań mieszanych, gdy dane wejściowe podane są $\mathrm{w}$ postaci macierzy wartości sygnału albo jawnej zależności funkcyjnej pomiędzy zmiennymi.

\section{Lit e r a t u r a}

[1] Bobrowski D., Modele i metody matematyczne teorii niezawodności, Wydawnictwo NaukowoTechniczne, Warszawa 1989.

[2] Jaźwińs ki J., Bezpieczeństwo systemów, Wydawnictwo Naukowe PWN Sp. z o. o., Warszawa 1993.
[3] Magiera J., Prognozowanie niezawodności w kombinowanym systemie transportowym, Zuzycie $i$ Niezawodność cz. III, PAN, Kraków 1998.

[4] Oprzędkiewicz J., Stolarski B., Komputerowe monitorowanie niezawodności. samochodów, PWN, Warszawa-Kraków 2000.

[5] P i e c P., Magiera J., Ocena zużycia i niezawodności pojazdów szynowych, Zakład Narodowy im. Ossolińskich - Wydawnictwo, Wrocław 1994.

[6] Praca zbiorowa pod redakcja S.I. Sokołowa, Badanie dynamiki $i$ wytrzymałości wagonów pasażerskich, Wydawnictwo Komunikacji $i$ Eqczności, Warszawa 1983.

[7] Sobański M. Mikulski J., Bezpieczeństwo systemów sterowania ruchem kolejowym $w$ świetle wymagań norm CENELE, Przeglad Kolejowy 11/99. 